\title{
Expression of hbz mRNA promotes survival in HTLV-1-infected cells with high DNA damage
}

\author{
Karina Flores ${ }^{1 *}$, Giovanni López ${ }^{1}$, Michael Talledo ${ }^{1}$, Carolina Alvarez $^{1}$, Elsa González ${ }^{1,2}$, Kristien Verdonck \\ Eduardo Gotuzzo ${ }^{1,2}$, Daniel Clark,3 \\ From 15th International Conference on Human Retroviruses: HTLV and Related Viruses \\ Leuven and Gembloux, Belgium. 5-8 June 2011
}

\section{Background}

HTLV1 may exert an initial pro-apoptotic stimulus via Tax-induced DNA damage. On the other hand, Hbz protein antagonizes some Tax effects on gene expression and hbz mRNA has been proposed as essential for maintaining oncogenesis. We hypothesize that expression of the hbz gene contributes to overcoming the pro-apoptotic signals in HTLV1 infected T-cells with DNA damage. To test this hypothesis we studied the expansion of infected cells with high DNA damage and investigated whether hbz mRNA supports survival of those cells.

\section{Aim and methods}

We measured HTLV1 proviral load (PVL) in two groups of HTLV-1-infected subjects showing (1) High DNA damage [HD] $(\mathrm{n}=18)$; and (2) Low DNA damage [LD] $(\mathrm{n}=9)$. Peripheral blood mononuclear cells were isolated to measure PVL and hbz mRNA levels by real time PCR, and the degree of DNA damage by comet assay (HD: $\geq 51$ comets/ 100cells; LD: $\leq 50$ comets/100cells). PVL was expressed as HTLV-1 tax copy number $/ 10^{4}$ PBMCs. Statistical analyses were based on non-parametric tests.

\section{Results}

PVL was not significantly different between both groups ( $\mathrm{p}=0.959$ ); however, we identified a cluster of high PVL (3168 $\pm 980 \mathrm{SD})$ in the HD group with detectable levels of hbz mRNA. Interestingly, no mRNA expression could be detected in the LD group.

\footnotetext{
* Correspondence: karita_life@hotmail.com

${ }^{1}$ Instituto de Medicina Tropical "Alexander von Humboldt", Universidad

Peruana Cayetano Heredia, Lima, Perú

Full list of author information is available at the end of the article
}

\section{Conclusion}

Our results suggest that hbz mRNA levels rise as DNA damage increases, which is consistent with our hypothesis. The absence of a negative association between PVL and DNA damage along with the detection of hbz mRNA only in HD subjects with high PVL further support our hypothesis.

\section{Author details \\ "Instituto de Medicina Tropical "Alexander von Humboldt", Universidad Peruana Cayetano Heredia, Lima, Perú. ${ }^{2}$ Facultad de Medicina Alberto Hurtado, Universidad Peruana Cayetano Heredia, Lima, Perú. ${ }^{3}$ Laboratorios de Investigación y Desarrollo (LID), Facultad de Ciencias y Filosofía, Universidad Peruana Cayetano Heredia, Lima, Perú.}

Published: 6 June 2011

\section{doi:10.1186/1742-4690-8-S1-A205}

Cite this article as: Flores et al:: Expression of hbz mRNA promotes survival in HTLV-1-infected cells with high DNA damage. Retrovirology 2011 8(Suppl 1):A205.

\section{Submit your next manuscript to BioMed Central and take full advantage of: \\ - Convenient online submission \\ - Thorough peer review \\ - No space constraints or color figure charges \\ - Immediate publication on acceptance \\ - Inclusion in PubMed, CAS, Scopus and Google Scholar \\ - Research which is freely available for redistribution \\ Submit your manuscript at

